cornea involving collagenous tissue does depend on the provision of a suitable fibrous tissue substratum and in turn on an adequate intake of ascorbic acid.

We are indebted to J. B. de V. Weir for help in design of the compression balance and for guidance in statistical analysis. We wish also to express our indebtedness to Roche Products Ltd. for the supply of ascorbic acid, and to the Rankin Medical Research Fund of the University of Glasgow for a grant to cover expenses.

\title{
REFERENCES
}

Arey, L. B. \& Covode, W. M. (1943). Anat. Rec. 86, 75.

Bourne, G. (1944). Lancet, 246, 688.

Buschke, W., Friedenwald, J. S. \& Fleischmann, W. (1943). Yohns Hopk. Hosp. Bull. 73, 143.

Campbell, F. W. \& Michaelson, I. C. (1949). Brit. Y. Ophthal. 33, 248.

Galloway, N. M., Garry, R. C. \& Hitchin, A. D. (1948-9). Brit. J. Nutrit. 2, 228.

Hartwell, S. W. (1929). Arch. Surg., Chicago, 19, 835.

Henkes, H. E. (1946). Ophthalmologica, I12, I13.

Jones, C. M., Bartlett, M. K., Ryan, A. E. \& Drummey, G. D. (1943). New Engl. F. Med. $229,642$.

Kellie, A. E. \& Zilva, S. S. (1939). Biochem. F. 33, 153.

Kuether, C. A., Telford, I. R. \& Roe, J. H. (1944). Y. Nutrit. $28,347$.

Mann, I. (1944). Brit. F. Ophthal. 28, 26.

Pirie, A. (1946). Biochem. F. 40, 96.

Schmid, A. F. \& Bürki, E. (1943). Ophthalmologica, ro5, 65.

Thomson, W. (1936). F. Hyg., Camb., 36, 24.

Wolbach, S. B. \& Howe, P. R. (1926). Arch. Path. Lab. Med. r, I.

Wolff, E. (1947). A Pathology of the Eye, and ed. Philadelphia: The Blakiston Company.

\section{Distribution of Radioactive Cobalt in the Rat}

\author{
By W. F. J. CUTHBERTSON, AUDREY A. FREE AND \\ DOREEN M. THORNTON \\ Research Division, Glaxo Laboratories Ltd., Greenford, Middlesex
}

(Received 2 Fanuary 1950)

The work to be reported here was carried out during an attempt to obtain vitamin $\mathbf{B}_{12}$ containing radioactive cobalt, ${ }^{60} \mathrm{Co}$. Previous experiments by Fantes, Page, Parker \& Smith (1949) have shown that it is not possible to label the vitamin $B_{12}$ molecule with radiocobalt by direct exchange with the cobalt of either radiocobalt chloride or hexamminocobaltic chloride, nor could exchange be demonstrated in the presence of liver tissue under the conditions employed. In the work to be reported here radioactive cobalt was administered under a variety of conditions to rats, in the hope that exchange reactions or biological synthesis would lead to the production of labelled vitamin $B_{12}$, and that this could then be isolated from the animals' livers.

\section{EXPERIMENTAL AND RESULTS}

General plan. Experiments of three types were carried out: ( 1 ) Short-term experiments were done to investigate the possibilities of biological exchange reactions, in which adult rats were maintained on a semi-synthetic diet low in cobalt and were given 
radioactive cobalt orally over a period of $I_{4}$ days. (2) In long-term experiments weanling rats were maintained on a diet containing a total of 0.012 p.p.m. of cobalt (diet RTCo, Table I, which contained 0.006 p.p.m. of added inorganic radioactive

Table 1. Composition of diet RTCo

$\begin{array}{lc}\text { Full cream roller-dried milk } & 49.5 \% \\ \text { Sucrose" } & 49.5 \% \\ \text { Sodium chloride A.R. } & \text { r\% } \\ \text { Aneurin hydrochloride } & 3.4 \text { p.p.m. } \\ \text { Copper sulphate }\left(\mathrm{CuSO}_{6} .5 \mathrm{H}_{2} \mathrm{O}\right) \dagger & 25 \text { p.p.m. } \\ \text { Ferric chloride }\left(\mathrm{FeCl}_{8}\right) \dagger & 30 \text { p.p.m. } \\ { }^{\circ 0} \mathrm{Co} & 2 \mu \mathrm{c} .\end{array}$

The ingredients were mixed thoroughly in the dry state and then water containing $2 \mu \mathrm{c} .{ }^{\circ 0} \mathrm{Co}$ was added and mixing continued to give a stiff dough.

* Extracted with ammoniacal alcohol and washed with ether.

$\dagger$ Freed from cobalt by method of Houk, Thomas \& Sherman (1946).

cobalt) for periods of up to 90 days. It was hoped that the radiocobalt would be incorporated in vitamin $\mathrm{B}_{12}$ either by intestinal synthesis involving the gut flora or by the tissues of the growing rat. (3) In view of the possibility that inorganic cobalt could not be used either by the tissues of the rat or by its intestinal commensals to form vitamin $B_{12}$, a further series of weanling animals was kept for 40 days on a vitamin $B_{12}$-free lowcobalt diet $\mathrm{RPV} / \mathrm{C}_{20}$, Table 2, including a supplement of radioactive-yeast extract given by mouth.

\section{Table 2. Diet $R P V / C 20$}

\begin{tabular}{|c|c|c|c|}
\hline \multicolumn{2}{|c|}{$\begin{array}{l}\text { Maize starch } \\
\text { Extracted casein } \\
\text { Salt mixture (de Loureiro, I93 I) } \\
\text { Arachis oil } \\
\text { SWADE }\end{array}$} & \multicolumn{2}{|c|}{$\begin{array}{r}64 \% \\
20 \% \\
5 \% \\
10 \% \\
1 \%\end{array}$} \\
\hline \multicolumn{2}{|c|}{$\begin{array}{l}\mathrm{SV}_{5} t \\
\text { Radioactive yeast extract, by mouth } \ddagger\end{array}$} & \multicolumn{2}{|c|}{$\begin{array}{l}10 \mathrm{ml} . / 100 \mathrm{~g} . \text { food } \\
0.5 \mathrm{ml} . / \mathrm{rat} \text { daily }\left(\equiv 0.2 \mathrm{I} \mu \mathrm{c},{ }^{80} \mathrm{Co} / \mathrm{day}\right)\end{array}$} \\
\hline - SWADE & \multicolumn{2}{|c|}{$\begin{array}{l}\text { Vitamin A concentrate } \\
\text { Calciferol } \\
\alpha \text {-Tocopherol acetate } \\
\text { Arachis oil to }\end{array}$} & $\begin{array}{l}1.2 \times 10^{6} \mathrm{i} . \mathrm{u} . \\
5 \mathrm{mg} .\left(0.2 \times 10^{6} \mathrm{i} . u .\right) \\
2.0 \mathrm{~g} . \\
100 \mathrm{~g} .\end{array}$ \\
\hline$+\mathrm{SV}_{5}$ & \multicolumn{2}{|c|}{$\begin{array}{l}\text { Choline chloride } \\
\text { Inositol } \\
\text { Nicotinic acid } \\
\text { Calcium D-pantothenate } \\
\text { Aneurin hydrochloride } \\
\text { Riboflavin } \\
\text { Pyridoxin hydrochloride } \\
\text { Biotin } \\
\text { p-Aminobenzoic acid } \\
\text { Folic acid } \\
\text { Ethyl alcohol }(95 \%) \\
\text { Water to }\end{array}$} & $\begin{array}{l}20 \mathrm{~g} . \\
2.2 \mathrm{~g} . \\
1.0 \mathrm{~g} . \\
\mathrm{I} \cdot 0 \mathrm{~g} . \\
300 \mathrm{mg} \text {. } \\
300 \mathrm{mg} \text {. } \\
80 \mathrm{mg} \text {. } \\
2 \mathrm{mg} \text {. } \\
0.75 \mathrm{~g} . \\
1.0 \mathrm{mg} \text {. } \\
100 \mathrm{ml} \text {. } \\
1000 \mathrm{ml} .\end{array}$ \\
\hline
\end{tabular}

$\mp$ Aqueous extract from yeast grown on synthetic cobalt-free medium to which ${ }^{60} \mathrm{Co}$ had been added at the rate of $2.5 \mu \mathrm{c} .{ }^{\circ} \mathrm{Co} / \mathrm{l}$.

This extract was prepared from yeast that had been grown in a medium containing radioactive cobalt. Yeast was used because of the reported effect of yeast extracts in 
controlling pernicious anaemia. Unpublished work in collaboration with $\mathrm{Dr} \mathrm{C}$. C. Ungley has shown that yeast extracts effective in this respect are unlikely to contain sufficient folic acid or vitamin $B_{12}$ to account for the haematological responses obtained. A possible explanation of these findings could be that yeast contains an organic cobalt compound that can be transformed into vitamin $B_{12}$ within the animal organism. We hoped that the feeding of rats on yeast extract containing such organically combined radioactive cobalt might lead to the synthesis of labelled vitamin $B_{12}$ within the animals.

Measurement of radioactivity. At the conclusion of these experiments the rats were killed. An attempt was made to isolate vitamin $B_{12}$ from their livers, but the amounts of vitamin $B_{12}$ found in all the groups were much smaller than expected and no labelled vitamin $B_{12}$ could be isolated. Radioactivity determinations were carried out on representative samples of the organs by the technique described by Braude, Free, Page \& Smith (1949). The samples were digested with sulphuric and nitric acids in the presence of about I mg. added unmarked cobalt as carrier. The digested material was diluted with about $2 \mathrm{~N}-\mathrm{HCl}$ and the solution was transferred to a Geiger-Müller liquid counter for radioactivity measurements. The results may be of interest because other workers have administered radioactive cobalt to animals only over short periods of time and in rather large doses. In our experiments repeated doses were given and generally in very small amounts over long periods of time.

\section{Short-term experiments on adult rats with diet RTCo}

Arrangement. In this experiment male and female adult rats ( $150-300 \mathrm{~g}$.) of our Wistar albino (WAG) or piebald (PVG) strain were used. In all, twenty animals were employed. The animals were kept in galvanized wire cages on screen bottoms. They were maintained on the experimental diet for 14 days, during which an additional $0.2 \mu \mathrm{c} .{ }^{60} \mathrm{Co}$ was given to each rat daily. The doses were administered orally in $0.1 \mathrm{ml}$. 10\% glucose.

After the test period, i.e. on the 15 th day of these experiments, all the animals were killed and organs were removed for determinations of radioactivity; the results are shown in Table $3(a)$.

Diet. The diet used (RTCo, Table I) was essentially that of Houk, Thomas \& Sherman (r946) with added iron and copper. Chemical analysis of the basal diet by Dr S. Ball showed it to contain 0.006 p.p.m. cobalt before the addition of the radioactive cobalt. 'The ingredients of the diet were mixed dry and to them was added the required amount of ${ }^{\circ 0} \mathrm{Co}$ in sufficient water to produce a stiff dough. The diet was fed $a d l i b$. and water was freely available to all animals. The complete diet RTCo contained on the dry basis total cobalt to the extent of 0.012 p.p.m.

\section{I.ong-term experiments on weanling rats with diet RTCo}

Arrangement. In this experiment 200 weanling rats of both sexes and strains were feed on diet RT'Co. The animals were housed in galvanized wire cages on screen bottoms and given distilled water ad lib. After 40 days on this regime sixty animals were killed and their organs were removed for determinations of radioactivity; the results are shown in Table $3(b)$. 
Vol. 4

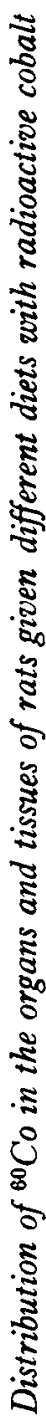

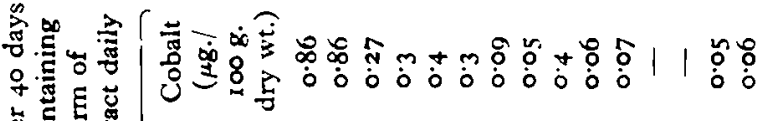

起磁总总

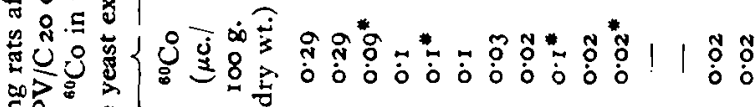

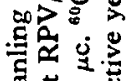

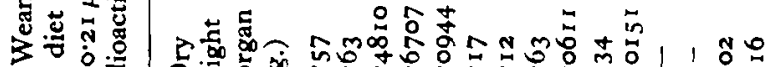
ङ

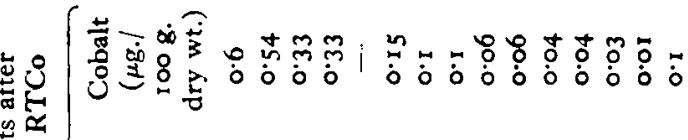

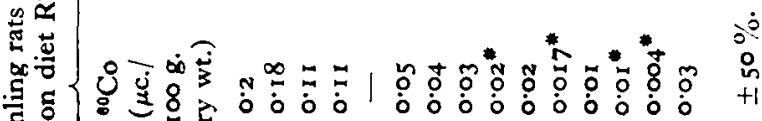

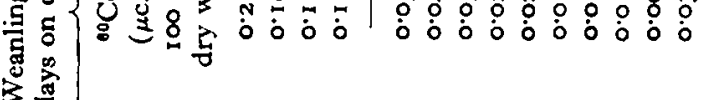

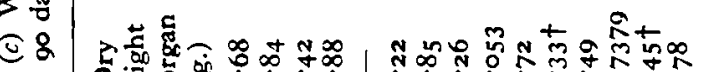

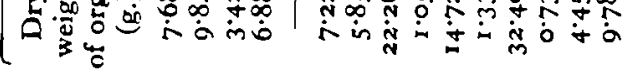

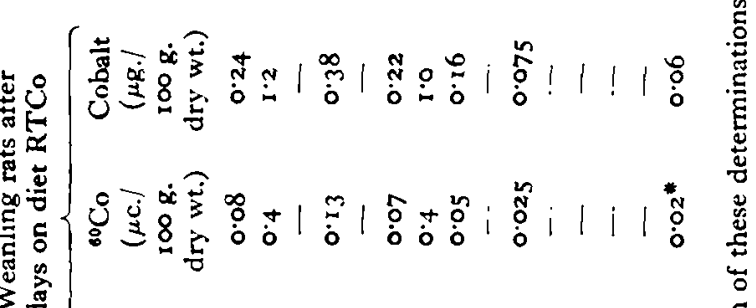

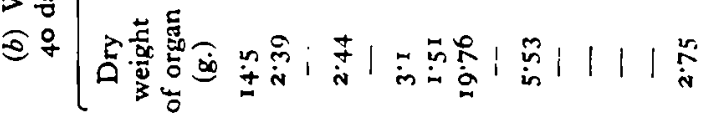
弮

绎

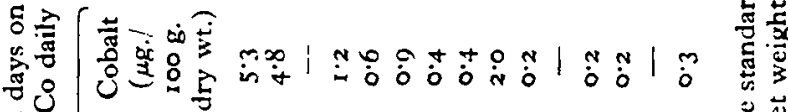

牙告

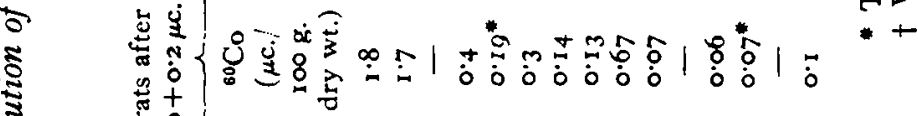

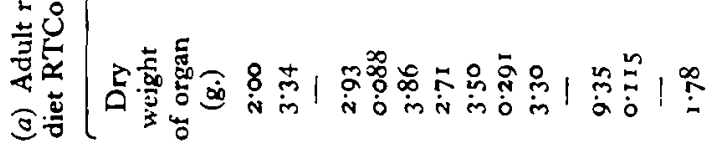

$\dot{m}$

$\frac{\sqrt{n}}{\frac{\pi}{n}}$

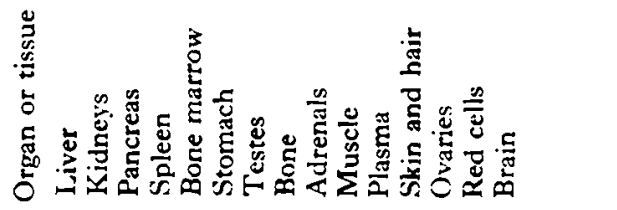


After a further $5^{\circ}$ days on the diet another forty animals were killed having then been on this diet for a period of 90 days in all; the organs were removed and their radioactivity determined, with the results shown in Table $3(c)$.

\section{Experiments in which radioactive yeast extract was fed}

Eight weanling rats, four of each strain, were maintained as in the other experiments, but were fed on diet $\mathrm{RPV} / \mathrm{C} 20$ (Table 2) ad lib. for 40 days and given a daily supplement of radioactive yeast extract; their average weight increased from 44 to $\mathrm{I} 68 \mathrm{~g}$. The animals were then killed and the organs were removed. The results of radioactivity determinations are shown in Table $3(d)$.

\section{Metabolic studies}

Adult rat. One animal was used in a metabolism study over a period of 7 days on diet RTCo. Apart from the ${ }^{60} \mathrm{Co}$ in the diet this animal received daily doses of $0.2 \mu \mathrm{c}$. ${ }^{60} \mathrm{Co}$ in $0.1 \mathrm{ml}$. $10 \%$ glucose given by mouth. From the 8 th to the 15 th day the urine and faeces were collected on filter-papers under the screen-bottomed cage and reserved for radioactivity determinations; the results are shown in Table $4 a$ together with

Table 4. Results of metabolic experiments (7-day periods)

\begin{tabular}{|c|c|c|c|}
\hline & $\begin{array}{l}\text { Adult rat on diet } \\
\text { RTCo }+0.2 \mu \mathrm{c} . \\
{ }^{\circ 0} \mathrm{Co} \text { daily } \\
a\end{array}$ & $\begin{array}{l}\text { Weanling rats } \\
\text { on diet RTCo } \\
b \quad\end{array}$ & $\begin{array}{c}\text { Weanling rats } \\
\text { on diet RPV/C } 20 \\
\left(0.21 \mu \mathrm{c} .{ }^{\circ 0} \mathrm{Co} \text { daily }\right) \\
c\end{array}$ \\
\hline $\begin{array}{l}\text { Intake of }{ }^{80} \mathrm{Co} / \mathrm{rat}_{\text {; week }}(\mu \mathrm{c} .) \\
\text { Urinary elimination of }{ }^{60} \mathrm{Co} / \text { rat } / \text { week } \\
(\mu \mathrm{c} .)\end{array}$ & $\begin{array}{l}1.57 \\
0.268\end{array}$ & $\begin{array}{l}0.099 \\
0.0578\end{array}$ & $\begin{array}{l}1 \cdot 47 \\
0 \cdot 126\end{array}$ \\
\hline $\begin{array}{l}\text { Faecal elimination of }{ }^{\circ 0} \mathrm{Co} / \mathrm{rat} / \text { week } \\
(\mu \mathrm{c} .)\end{array}$ & $1 \cdot 22$ & 0.0361 & $1 \cdot 24$ \\
\hline $\begin{array}{l}\text { Retention of }{ }^{\circ 0} \mathrm{Co} \text {;rat/week } \\
\text { (by difference) }(\mu \mathrm{c} .)\end{array}$ & $\begin{array}{l}0.087 \\
(5 \%)\end{array}$ & $\begin{array}{l}0.0050 \\
(5 \%)\end{array}$ & $\begin{array}{l}0.1035 \\
(7 \%)\end{array}$ \\
\hline
\end{tabular}

records of ${ }^{60} \mathrm{Co}$ intake. In this, as in the following metabolism experiment, the faeces and filter-papers containing urine were wet-ashed in the presence of carrier cobalt and radioactivity determinations were carried out by the technique applied to the organs.

Weanling rats. Threc newly weaned animals on diet R'TCo were studied from the $7^{\text {th }}$ to $15^{\text {th }}$ day on the same diet and under the same conditions as the adult animal, except that no ${ }^{60} \mathrm{Co}$ was administered other than that ingested in the diet. Food intake and dietary intake and faecal and urinary output of ${ }^{60} \mathrm{Co}$ were determined, with the results shown in Table $4 b$.

Metabolism studies were carried out on the animals given radioactive yeast extract. Over a period of 7 days, i.e. from the $7^{\text {th }}$ to $15^{\text {th }}$ day of experiment, food consumption was measured and the output of ${ }^{60} \mathrm{Co}$ was determined, with the results shown in Table $4 c$. 'The ${ }^{60} \mathrm{Co}$ contents of the faecal samples and of the papers on which urine was collected were determined by the technique already mentioned. 
DISCUSSION

Metabolic experiments. The retention of tracer cobalt expressed as percentage of the amount fed was very similar in the three different groups, though the absolute amounts retained were much greater at the higher dosage levels. The retention of cobalt in these metabolism experiments was of the same order as in those reported by Houk et al. (1946), who fed cobalt at the rate of 0.08 p.p.m., but much lower than the $30-40 \%$ retention reported by them when feeding diets containing 0.003 p.p.m. cobalt.

Distribution of radiocobalt. In agreement with those of Josland \& McNaught (1937-8) and Copp \& Greenberg (194I), our results show that cobalt is preferentially concentrated in the liver, kidneys and spleen. The animals maintained on the low cobalt $\operatorname{diet}$ (RTCo-0.012 p.p.m. total cobalt) containing 50\% added tracer cobalt and $50 \%$ unlabelled cobalt accumulated amounts of the order of $0.02-\mathrm{I} \cdot 0 \mu \mathrm{g}$. cobalt $/ \mathrm{r} 00 \mathrm{~g}$. dry weight of tissue. The animals given larger doses of cobalt for a short time stored rather more ${ }^{80} \mathrm{Co}$ in their tissues. The distribution of radiocobalt between the different organs in these experiments agrees with the distribution of cobalt found by Josland \& McNaught, who also studied rats over prolonged periods, although the total amounts of cobalt deposited in the organs of our animals were much less than the amounts found in theirs; this was to be expected, since their animals were fed on stock diet with or without the addition of large amounts of cobalt.

The distribution of cobalt, found in the organs during this work, and the amounts deposited, agree on the whole with the findings of Copp \& Greenberg (194I), except that the proportion deposited in the livers of their animals was rather smaller. They gave rather larger amounts ( $10 \mu \mathrm{g}$. tracer cobalt) orally or parenterally as single doses and the animals were studied over a period of a few days only; the differences in cobalt distribution may be explained on the assumption that the turnover of cobalt is greater in the kidneys, spleen and pancreas than in the liver.

The radioactivity of the organs found in these experiments may be used to calculate the total cobalt content only on the assumption that the radiocobalt is freely exchangeable with all the body cobalt and absorbed dietary cobalt. We obtained some evidence that this is in fact not so. Comparison of the tracer cobalt content with the total cobalt content (as determined by colorimetric analysis) of the livers of the animals kept on diet RTCo for 90 days showed the ratio of tracer cobalt to total cobalt to be $1: 50$ in the liver, whereas the ratio of tracer to total cobalt in the diet was $I: 2$, so that either the bulk of the liver cobalt does not exchange with added inorganic cobalt or our diet had been very seriously contaminated with cobalt. Chemical analysis of the diet showed that contamination had not occurred, but there remained the possibility that the animals could have obtained cobalt from the metal cages. This was considered to be very unlikely, for the cages were well galvanized and the animals showed no signs of gnawing them. Faeces collected for cobalt analysis were unfortunately lost during preparation; however, faecal material from another group of animals showed the ratio of tracer cobalt to total cobalt to be $\mathrm{x}: 3 \cdot 4$ instead of the expected $\mathrm{I}: 3$, demonstrating that there had been no gross increased consumption of cobalt. 


\section{SUMMARY}

I. 'The metabolism of dietary ${ }^{60} \mathrm{Co}$ was studied in the rat. 'The amounts used were of the order met in normal or cobalt-low diets, i.e. about $0.01-0.06$ p.p.m. cobalt.

2. When labelled cobalt was administered over this range the retention during the first I4-day period on the diet was $5-7 \%$ of the total intake.

3. The concentration of labelled cobalt in the organs of rats maintained on low cobalt diets and given small amounts of labelled cobalt $\left({ }^{80} \mathrm{Co}\right)$ was studied over periods from 14 to 90 days on the experimental diets. Higher concentrations were found in the liver, kidneys, spleen and pancreas than in the other organs studied.

Our thanks are due to the Medical Research Council for a generous gift of ${ }^{60} \mathrm{Co}$ and to the U.S. Atomic Energy Commission which supplied this tracer cobalt, and also to Dr J. E. Page for valuable advice on the estimation of radiocobalt.

\section{REFERENCES}

Braude, R., Free, A., Page, J. E. \& Smith, E. L. (1949). Brit. F. Nutrit. 3, 289. Copp, D. H. \& Greenberg, D. M. (r94I). Proc. Nat. Acad. Sci., Wash., 27, I 53. de Loureiro, J. A. (193I). Arch. Patol., Lisboa, 3, 72.

Fantes, K. H., Page, J. E., Parker, L. F. \& Smith, E. L. (1949). Proc. roy. Soc. B, 136, 592.

Houk, A. E. H., Thomas, A. W. \& Sherman, H. C. (1946). F. Nutrit. 31, 609.

Josland, S. W. \& McNaught, K. J. (1937-8). N.Z. F. Sci. Tech. 19, 536. 